\title{
How exclusion from the WHO is affecting health care in Taiwan
}

\author{
n Cite as: CMAJ 2019 August 6;191:E872-3. doi: 10.1503/cmaj.109-5778
}

Posted on cmajnews.com on July 17, 2019.

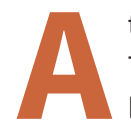
t the World Conference on Tobacco or Health in South Africa last year, Kelley Lee, a professor of globalization and health at Simon Fraser University in Vancouver, was shocked to see several academics escorted out. They appeared "very upset," and she learned they were Taiwanese scholars.

Though the island of Taiwan functions as an independent democracy, leaders of communist China claim it as a province, which is accepted by the United Nations and its agencies, including the World Health Organization (WHO). At the conference, a Chinese official asked the WHO to intervene. As a sponsor, the WHO asked the Taiwanese academics to leave, according to blogging and reporting in the journal Tobacco Control. Conference organizers took down the Taiwanese professors' posters and removed their presentation from the agenda.

Today, demonstrators in Hong Kong, a semi-autonomous part of China, have gained worldwide support for protests against a proposed law that would remove the firewall between the city's legal system and the politicallycontrolled courts of Mainland China. On nearby Taiwan, thousands rallied to show solidarity. Taiwan's leaders hope to draw attention to parallels between their situation and Hong Kong's, yet in the global health realm, many academics know little about Taiwan's plight.

Last year, in the lead up to the World Health Assembly (WHA), the WHO's annual meet- ing, Taiwan's foreign affairs ministry brought international journalists to Taipei to hear government leaders advocate for access to the WHO. This year, the government held rallies in cities around the world during the months before the WHA. John McKay, a Canadian member of parliament, attended a Toronto walkathon to support the cause. At the 2019 WHA, Dr. Theresa Tam, Canada's chief public health officer, was among several health leaders who spoke to the issue, albeit indirectly. "Politics should not impede people's access to the global health system," said Tam.
According to Lee, who studied the situation for the Brookings Institute, Taiwan is unlikely to succeed in its mission. The WHO is bound by its 2005 Memorandum of Understanding with the People's Republic of China that essentially requires Beijing's approval for Taiwan to participate in WHO activities. One ripple effect of the Hong Kong protests is that Taiwan's leading political parties have ramped up their pro-independence rhetoric, Lee said, so "a WHO détente is not going to happen very soon." In a statement to CMAJ, the Foundation of Medical Professionals Alliance in Taiwan concurred, suggesting the

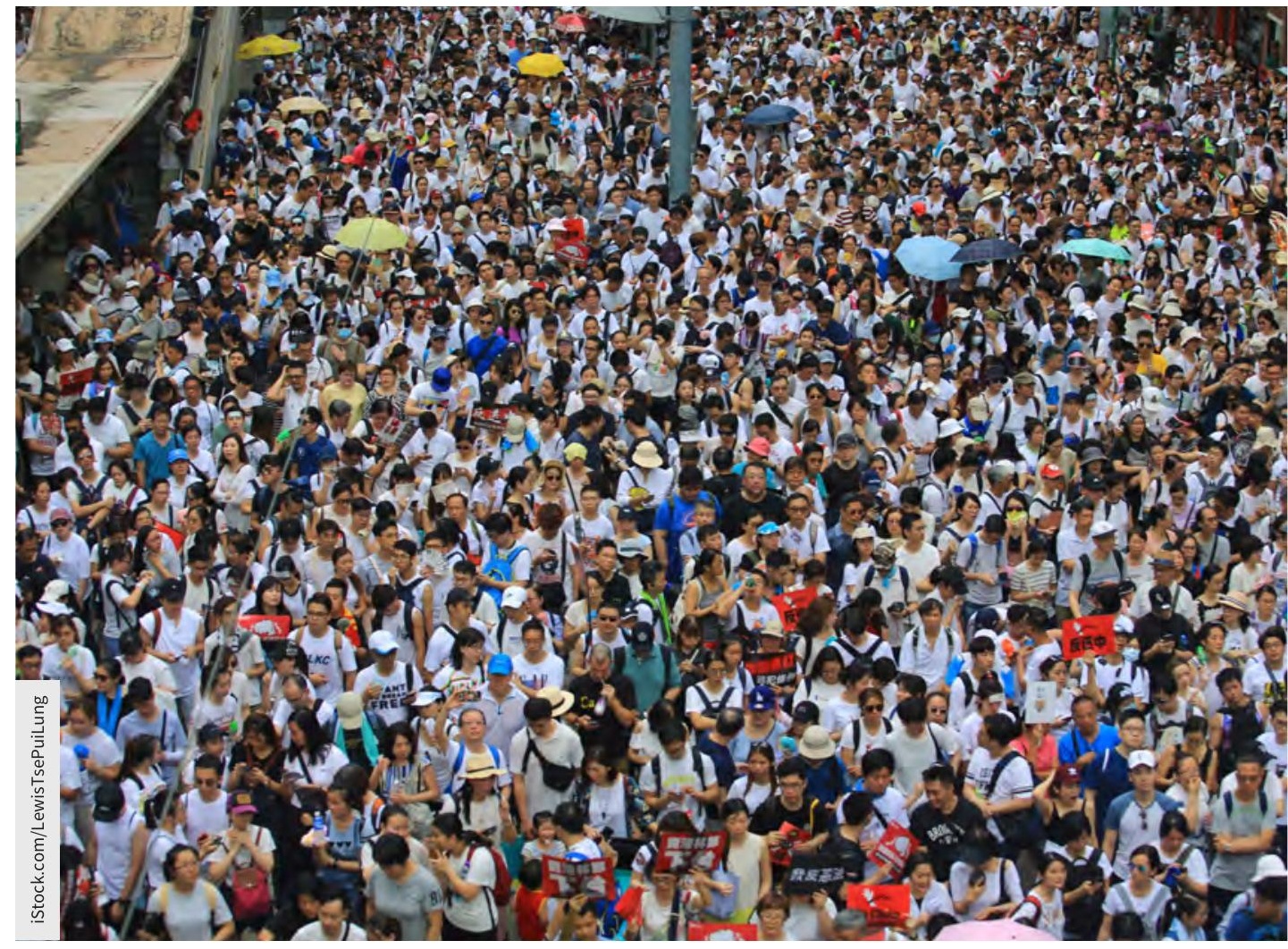

Taiwan's leaders have shown solidarity with Hong Kong protestors and hope to draw attention to parallels with their own problems with China. 
WHO issue is "provocative to [China President] Xi's authority."

Taiwanese health leaders believe the island's exclusion from the WHO has put its population at serious risk. They point to an outbreak of hand-foot-and-mouth disease in 1998, which killed 78 people, and to a severe acute respiratory syndrome (SARS) outbreak in 2003. SARS emerged in Taiwan just days after the WHO issued global alerts about the outbreak in March. Taiwanese health authorities said they asked the WHO for support but received no response.

According to a report by the US General Accounting Office, the WHO transmitted Taiwan's requests to the US Centers for Disease Control and Prevention (CDC); the US sent experts immediately. The CDC reported that, by the end of April, SARS was spreading so rapidly in Taiwan that the number of probable cases more than tripled in a 10-day period, overwhelming Taiwanese hospitals. However, WHO experts arrived in Taiwan only when China gave permission, nearly seven weeks after the outbreak began. The SARS tragedy left 181 Taiwanese dead, including three doctors and four nurses, according to a report in the International Journal of Infectious Disease.

Six years later, the memory of the SARS experience, along with worldwide fears that pandemic flu could be emerging in Asia, paved the way for change in Taiwan's relationship with the WHO. In 2009, during a period when relations between Taiwan and Beijing were improving, Taiwan began attending the WHA and WHO technical meetings as an observer under the name Chinese Taipei. But in 2016, Taiwan elected its current proindependence president and China withdrew its approval of the observership arrangement the following year.

Taiwan has since had limited access to the WHO, missing more than half of WHO technical meetings because Beijing's permission is needed to attend. "Since WHO won't provide Taiwan with infectious diseases info, the chance of outbreak remains high," stated the Foundation of Medical Professionals Alliance in Taiwan.
Taiwan expert Dennis Hickey, a political science professor at Missouri State University, said "the WHO ought to have Taiwan in as an observer and I don't think it should depend on how politics change from day to day." The WHO has not replied to CMAJ's requests for comment.

A current example of the price Taiwan is paying for its exclusion from the WHO and other UN agencies is related to the spread of swine virus in Mainland China and other Asian countries. The virus has led to China culling one-third of its pig herd, and the United Kingdom had a scare this month when port authorities found infected meat in Northern Ireland. Taiwan is "unable to coordinate dealing with that issue with the mainland, and people are flying in on airplanes [to Taiwan] with pork," said Steven Goldstein, director of the Taiwan Studies Workshop at Harvard University. "But politics are politics," he said, adding that Taiwan's situation with China is at a stalemate with no end in sight.

Miriam Shuchman, Toronto, Ont. 